\title{
Integrasi Ruang Biru pada Rencana Tata Ruang Wilayah Sebagai Instrumen Mitigasi Bencana Banjir di Kota Semarang
}

\author{
Blue Space Integration in Regional Spatial Planning as Instrument \\ for Flood Disaster Mitigation in Semarang City
}

\author{
Khristiana Dwi Astuti ${ }^{1}$, P Pangi ${ }^{1}$, S Sariffuddin ${ }^{2}$ \\ Diterima: 6 Maret 2019 \\ Disetujui: 19 November 2019
}

\begin{abstract}
Abstrak: Rencana tata ruang sebagai pedoman dalam pemanfaatan ruang mengatur berbagai kegiatan yang diijinkan dalam suatu ruang dengan mempertimbangkan pada berbagai implikasi yang dapat terjadi, termasuk bencana alam yang mungkin saja tidak dapat diprediksi. Kota Semarang dengan kondisi topografi yang beragam mempunyai potensi bencana alam salah satunya bencana banjir. Upaya mitigasi bencana banjir salah satunya didasarkan pada keberadaan ruang terbuka hijau maupun non hijau sebagai area resapan air. Namun pada kenyataannya substansi dalam rencana tata ruang belum secara jelas mengatur tentang ruang biru perkotaan. Penelitian ini bertujuan untuk dapat mengintegrasikan ruang biru pada substansi rencana tata ruang wilayah sebagai instrument mitigasi bencana di Kota Semarang. Penelitian dilakukan melalui review terhadap substansi rencana tata ruang dan upaya mitigasi bencana banjir yang telah dilakukan di Kota Semarang. Berdasarkan hasil kajian yang telah dilakukan, integrasi rencana ruang biru dapat diintegrasikan pada beberapa muatan rencana tata ruang wilayah, mulai dari perumusan tujuan, kebijakan, dan strategi penataan ruang hingga arahan pengendalian pemanfaatan ruang.
\end{abstract}

Kata kunci: ruang biru, rencana tata ruang, mitigasi

\begin{abstract}
Spatial planning as a guidance in spatial use, arrange various permitted activities in a space by considering various implications including natural disasters which may not be predictable. Semarang City with diverse topographic conditions has the potential for natural disasters, including flood. One of the flood disaster mitigation efforts is based on the existence of green space and bluespace as water catchment areas. But in fact, the substance of spatial planning has not clearly regulated the urban blue space. This study aims to integrate the blue space in the substance of regional spatial planning as a disaster mitigation instrument in the Semarang City. The research was conducted through a review of the substance of the spatial planning and flood disaster mitigation efforts that have been carried out in Semarang City. Based on the results of the studies that have been conducted, the integration of the blue space plan can be integrated in several contents of the regional spatial plan, starting from the formulation of objectives, policies, and spatial planning strategies to the direction of controlling spatial use.
\end{abstract}

Keywords: blue space, spatial planning, mitigation

\footnotetext{
${ }^{1}$ Departmen Sipil dan Perencanaan, Sekolah Vokasi, Universitas Diponegoro

${ }^{2}$ Departmen Perencanaan Wilayah dan Kota, Fakultas Teknik, Universitas Diponegoro
} 


\section{PENDAHULUAN}

Undang-Undang No. 26 Tahun 2007 tentang Penataan Ruang mengamanatkan bahwa rencana tata ruang merupakan pedoman dalam kegiatan pemanfaatan ruang dan pengendalian pemanfaatan ruang. Dengan demikian, di dalam rencana tata ruang tersebut perlu mengatur berbagai hal atau kegiatan yang diijinkan dengan mempertimbangkan pada berbagai implikasi yang mungkin saja terjadi sebagai akibat dari kegiatan pemanfaatan ruang.

Kegiatan pemanfaatan ruang pada suatu wilayah atau kota tentunya sangat kompleks karena terkait dengan ruang yang ada (container) maupun apa yang ada di dalamnya (content) (Soetomo, 2009). Container sebagai wadah bagi berbagai fungsi dan aktivitas yang berkembang di dalamnya, perlu diatur supaya pemanfaatannya dapat diolah secara bijaksana sehingga manusia dapat hidup berkelanjutan. Pengaturan ini terdapat pada rencana tata ruang kota, yang memuat rencana penyediaan ruang, salah satunya berupa ruang terbuka non hijau (RTNH). RTNH merupakan ruang terbuka di wilayah kota/kawasan perkotaan yang tidak termasuk dalam kategori ruang terbuka hijau, yaitu berupa lahan yang diperkeras maupun yang berupa badan air atau ruang terbuka biru (Haeffner, Jackson-smith, Buchert, \& Risley, 2017).

Ruang terbuka biru (RTB) merupakan elemen penting dalam perencanaan wilayah perkotaan. RTB bukan menjadi pelengkap dalam suatu perencanaan, tapi zona wajib yang harus ada dalam perencanaan tata ruang wilayah kota (Departemen Pekerjaan Umum, 2009). Hal tersebut juga dipertegas bahwa di dalam Peraturan Pemerintah Nomor 15 Tahun 2010 tentang Penyelenggaraan Penataan Ruang bahwa dalam konsepsi rencana penataan ruang harus mencantumkan rencana penyediaan dan pemanfaatan ruang terbuka non hijau.

RTB tidak hanya berfungsi sebagai penyimpan air namun juga memiliki fungsi sebagai wisata, pembangkit listrik, dan sarana transportasi utama di beberapa wilayah di Indonesia. Fungsi ekologis lain adalah sebagai tempat biodiversitas lain yang tidak dimiliki RTH, mampu menyerap karbon, menurunkan suhu, dan sebagai aset ekologi wilayah, karena RTB memiliki daya serap yang baik untuk mengalirkan dan menyaring air (Planning Department, 2016). Oleh karena itu apabila dikonservasi dengan baik maka ruang biru adalah aset bagi wilayah tersebut. Pada kenyataannya RTB kurang diakomodir sebagai bagian dari muatan rencana tata ruang. Padahal, jika dihadapkan pada berbagai permasalahan tata ruang yang dihadapi saat ini, terutama kaitannya dengan bencana yang terjadi, maka rencana ruang terbuka non hijau ini sangat diperlukan sebagai instrument mitigasi bencana yang ada.

Menurut laporan dari BNPB melalui dibi.bnpb.go.id, kejadian bencana di Indonesia terus meningkat dari tahun 2000 hingga saat ini di tahun 2018, khususnya bencana hidrometeorologi seperti banjir, angin topan, dan kenaikan muka air laut. Bencana ini menjadi ancaman terbesar dibandingkan tipe bencana alam lainnya yang juga terjadi di Indonesia. EM-DAT, sebuah lembaga penelitian kebencanaan dunia mencatat adanya hubungan signifikan antara kejadian bencana hidro-meteorologi dengan kerugian ekonomi. Disamping itu bencana ini pun mampu memberi dampak yang sangat signifikan di bidang sosial dan kesehatan. Dengan banyaknya bencana yang terjadi di Indonesia, salah satunya di Kota Semarang dalam kurun waktu tersebut tentunya berdampak pada semakin tingginya pengeluaran pemerintah untuk penanggulangan bencana (CCROM, 2010).

Kota Semarang sebagai salah satu daerah rawan banjir di Indonesia, dapat memanfaatkan pengembangan RTB sebagai pengendali banjir ditengah semakin menyempitnya daerah resapan air. Hal ini ditinjau dari permasalahan penyebab banjir di Kota Semarang, yang salah satunya dipengaruhi oleh adanya perubahan guna lahan dari ruang terbuka menjadi lahan terbangun (Handayani \& Rudiarto, 2014). Pada tahun 1990, luas vegetasi hijau adalah seluas 391,23 km2, menurun menjadi $264,24 \mathrm{~km}^{2}$ di tahun 2000 kemudian semakin mengalami penurunan menjadi 242,14 $\mathrm{km}^{2}$ di tahun 2015 (Sejati, Buchori, \& Rudiarto, 2018). 
Merujuk pada rencana tata ruang wilayah Kota Semarang, pengendalian banjir yang diakomodir melalui ketersediaan RTB diupayakan melalui kebijakan dan strategi pengembangan struktur ruang terutama yang berfokus pada pemberian ruang air. Disamping itu juga diupayakan melalui pengembangan jangkauan pelayanan sistem prasarana sumberdaya air. Upaya tersebut meliputi pengembangan sistem prasarana air baku dan irigasi serta pengendalian rob dan banjir. Dari keseluruhan substansi yang mengatur upaya pengendalian banjir tersebut, belum secara jelas merefleksikan bentuk tata ruang itu sendiri sebagai instrumen mitigasi bencana. Berbeda dengan yang sudah dilakukan di China dengan mengusung konsep sponge cities dimana pemerintah China berusaha semaksimal mungkin membuat 'kantung-kantung' resapan air hujan (Tingsanchali, 2012)(Ka et al., 2018; Tingsanchali, 2012) guna mengurangi limpasan air sehingga secara langsung pencegahan bencana banjir dapat dilakukan. Selain pemerintan China ada juga pemerintah Belanda yang lebih mementingkan manajemen infrastruktur pengairan perkotaan melalui dam dan kanalkanal pengendali banjir (Sobolewska-mikulska \& Ritzema, 2018).

Terdapat beberapa penelitian terkait dengan peran ruang biru dalam tata ruang yang sudah pernah dilakukan sebelumnya. Dalam penelitian tersebut membahas peran ruang biru dalam keberlanjutan pembangunan perkotaan dilihat dari dari sudut pandang sosial budaya, ekonomi dan lingkungan (Wessells, 2014). Ada pula penelitian mengenai ruang biru sebagai salah satu pembentuk faktor keindahan arsitektural dalam menciptakan keserasian dan keseimbangan antara ruang terbangun dan tidak terbangun dalam perkotaan (Katarína Čákyová, $\left.{ }^{*}, 2018\right)$, dan yang terakhir adalah penelitian mengenai peran ruang biru sebagai salah satu elemen ruang terbuka publik yang berkontribusi dalam manajemen bencana (R.R.J.C. Jayakody, D. Amarathunga, 2018). Namun secara rinci bahasan mengenai peran RTB sebagai bagian dari tata ruang yang perlu diakomodir untuk memperjelas peran tata ruang sebagai dokumen mitigasi bencana belum pernah dilakukan sebelumnya. Berdasarkan pada beberapa hal tersebut maka peran rencana tata ruang sebagai dasar bagi pemanfaatan ruang serta pengendalian terhadap pemanfaatan ruang di Kota Semarang yang di dalamnya memuat perencanaan mengenai RTB sangat penting untuk dilakukan terutama kaitannya dengan upaya mitigasi bencana yang ada.

\section{METODOLOGI}

Penelitian ini dilakukan untuk mengintegrasikan rencana tata ruang khususnya terkait dengan ruang biru perkotaan terhadap upaya mitigasi bencana banjir di Kota Semarang. Kajian dilakukan terhadap substansi rencana tata ruang yang ada, yakni Rencana Tata Ruang Wilayah (RTRW) Kota Semarang Tahun 2011-2031, dan beberapa penelitian yang sudah dilakukan sebelumnya terhadap upaya mitigasi banjir di Kota Semarang. Merujuk pada tujuan penelitian, adapun bahasan difokuskan pada upaya mitigasi bencana banjir yang sudah ada di Kota Semarang, substansi RTRW yang memuat bahasan mengenai ketersediaan ruang air dan kaitannya terhadap upaya mitigasi bencana di Kota Semarang, dan integrasi RTB di dalam RTRW sebagai instrumen untuk mitigasi bencana banjir.

\section{DISKUSI DAN PEMBAHASAN}

\section{Mitigasi Bencana Banjir di Kota Semarang}

Bencana hidro-meteorological merupakan bencana terjadi sebagai dampak dari fenomena meteorologi, yang dapat berupa banjir, topan dan kenaikan muka air laut. Bencana ini menempati posisi tertinggi di Indonesia. Dari tahun 2000 - 2018, kejadian bencana hydrometeorological dunia terus naik, kondisi yang sama juga untuk kejadian hidrometeorological di Indonesia. Kerugian yang ditimbulkanpun mengikutinya, semakin naik dari tahun ke tahun, termasuk yang terjadi di Kota Semarang. 
Penelitian mengenai perubahan iklim di Kota Semarang pertama kali dilakukan oleh CCROM (2010) melalui laporannya yang berjudul Kajian Kerentanan dan Adaptasi terhadap Perubahan Iklim di Kota Semarang. CCROM (2010) menyimpulkan telah terjadi perubahan iklim di Kota Semarang yang ditandai oleh perubahan trend dan sifat dari beberapa unsur iklim seperti suhu dan curah hujan. Variabilitas curah hujan Kota Semarang itu sendiri dipengaruhi oleh El Nino-Southern Oscillation (ENSO) dan Indian Ocean Dipole (IOD). ENSO berperan penting mempengaruhi kondisi iklim tropis Indonesia terutama curah hujan. Selain ENSO, curah hujan di Indonesia juga dipengaruhi oleh IOD. Penelitian yang dilakukan oleh CCROM (2010) menunjukkan bahwa terdapat pengaruh kuat ENSO terhadap keragaman curah hujan Kota Semarang yang terjadi selama musim kering dan periode transisi monsoon.

Berkaitan dengan banjir dan kekeringan yang terjadi di Kota Semarang, CCROM (2010) menemukan adanya fluktuasi curah hujan akibat perubahan iklim ekstrim yang terjadi pada tahun kejadian ENSO dan/atau IOD. Batas kritis curah hujan Kota Semarang adalah $302 \mathrm{~mm}$ disaat musim hujan dan sebesar $84 \mathrm{~mm}$ di saat musim kemarau (CCROM, 2010). Batas kritis ini menjadi acuan, jikalau curah hujan melebihi $302 \mathrm{~mm}$ maka diperkirakan akan terjadi limpasan yang lebih besar dan berdampak pada banjir, sedangkan jika kurang dari $84 \mathrm{~mm}$ maka akan terjadi kekurangan air atau kekeringan. Namun jika kita bandingkan dengan jumlah kejadikan bencana banjir di Kota Semarang menunjukkan kondisi yang berbeda. Bergesernya musim kemarau dan musim penghujan di Kota Semarang ternyata tidak menunjukkan kenaikan curah hujan yang tinggi, namun jumlah kejadian banjir di Kota Semarang semakin tahun semakin meningkat. Oleh karena itu, tahapan selanjutnya adalah mengkaji bagaimana perkembangan areal terbangun di Kota Semarang.

Penelitian mengenai hubungan pertumbuhan penduduk perkotaan dengan perubahan guna lahan di Kota Semarang telah dilakukan oleh Handayani (2014), dan Sejati (2018). Kedua penelitian ini menyimpulkan adanya perubahan guna lahan dari ruang terbuka ke ruang terbangun yang mengokupansi (occupy) lahan hijau. Penelitian terbaru dari Sejati (2018) menginformasikan adanya lonjakan kenaikan daerah lahan terbangun dari 56,31 $\mathrm{Km} 2$ di tahun 1990 menjadi 89,44 Km2 di tahun 2000 kemudian bertambah lagi menjadi $180 \mathrm{Km} 2$ di tahun 2015. Ada kenaikan lebih dari $91.09 \mathrm{Km} 2$ dalam kurun waktu 15 tahun (2000 - 2015), jauh lebih tinggi dibandingkan kenaikan built-up area di tahun 1990-2000 yaitu sebesar $33.13 \mathrm{~km} 2$. Konsekuensi yang ditimbulkan dari pertumbuhan built-up area ini adalah semakin rendahnya area vegetasi hijau. Dari luas vegetasi hijau 391,23 km2 di tahun 1990 menurun menjadi $264,24 \mathrm{~km} 2$ di tahun 2000 kemudian semakin menurun di tahun 2015 menjadi 242,14 km2 (Sejati et al., 2018).

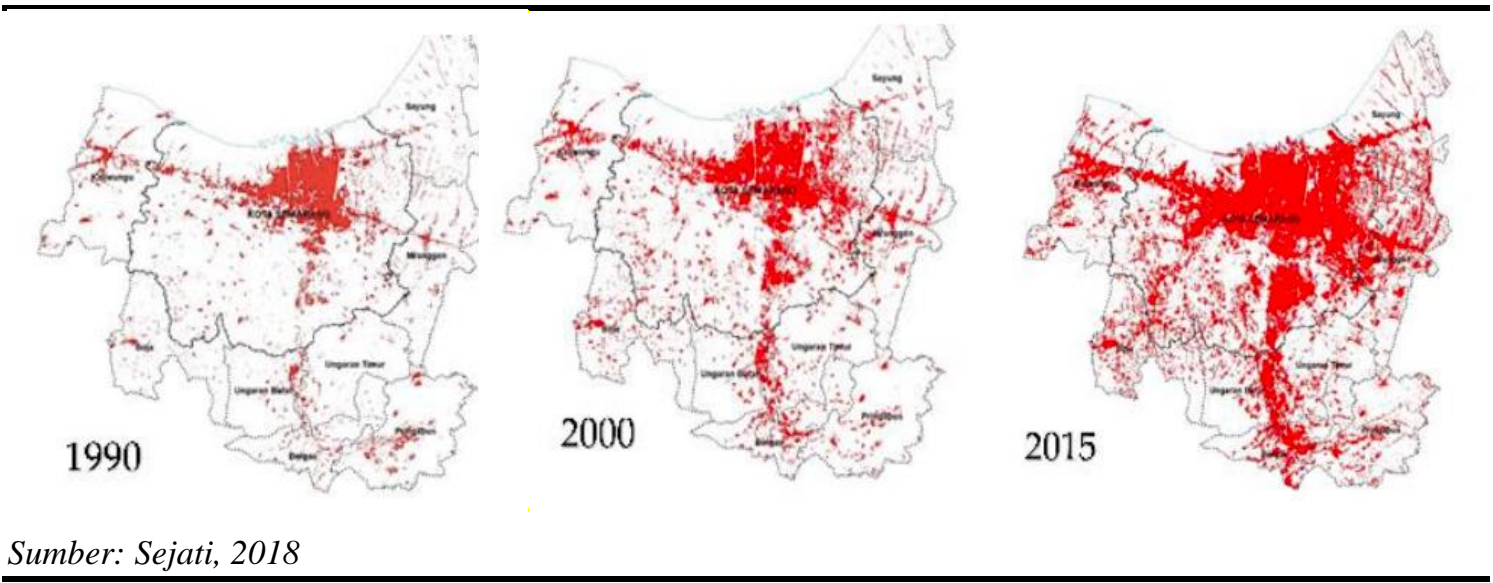

Gambar 1. Perkembangan Lahan Terbangun di Kota Semarang Tahun 1990-2015 
Membandingkan hasil penelitian yang dilakukan oleh CCROM (2010) dengan hasil penelitian yang dilakukan oleh Sejati (2018) dan Handayani (2014) maka sangat logis jika tingginya kejadian banjir di Kota Semarang ini bukanlah masalah hidro-meteorological semata. Tidak signifikannya kenaikan curah hujan dan perubahan iklim ternyata berkebalikan dengan berkurangnya luasan areal tangkapan air di Kota Semarang. Sehingga masalah utama semakin tingginya masalah banjir di Kota Semarang sebenarnya adalah pada permasalahan tata guna lahan.

Trend perkembangan lahan terbangun mengokupansi lahan non terbangun yang berfungsi sebagai area resapan. Akibatnya area resapan yang juga berfungsi sebagai area tangkapan air akan semakin berkurang (Sarifuddin \& Susanti, 2011). Berkurangnya area resapan berimplikasi meningkatnya limpasan air permukaan (run-off). Oleh karena itu untuk mengurangi limpasan air permukaan tersebut perlu meningkatkan infiltrasi, evapotranspirasi dari daerah tangkapan air, maupun optimalisasi fungsi ruang-ruang khusus air berupa sungai, danau, waduk, dan sebagainya (Tingsanchali, 2012). Hal ini diperlukan agar resiko maupun kerugian yang harus ditanggung akibat adanya bencana dapat diminimalkan,

Salah satu upaya yang telah dilakukan untuk mengatasi banjir di Kota Semarang adalah dengan normalisasi 2 sungai besar yang melintasi Kota Semarang, yaitu banjir kanal barat dan banjir kanal timur (Sariffuddin, Astuti, Farhaeni, \& Wahdah, 2017). Berdasarkan paparan yang disampaikan oleh Walikota Semarang di forum International Conference on Indonesian Social and Political Enquiries tanggal 22 Oktober 2018, bahwa normalisasi sungai tahap pertama yang dilakukan pada Sungai Banjir Kanal Barat pada tahun 2010 telah memberikan dampak yang signifikan dalam mengurangi wilayah rawan banjir. Pada tahun 2011 wilayah rawan banjir di Kota Semarang adalah seluas 41,02\% dari total wilayah Kota Semarang menjadi $21,4 \%$ pada tahun 2017. Upaya lain yang dilakukan pemerintah untuk menanggulangi banjir yaitu berupa kebijakan pembangunan infrastruktur pengendali banjir berupa kolam retensi yang masih dalam tahap pembangunan.

Hal ini menunjukkan bahwa salah satu upaya untuk mengurangi dampak bencana banjir adalah dengan memaksimalkan peran RTB. Hal tersebut secara signifikan dapat disikapi melalui integrasi RTB dalam rencana tata ruang. Melalui optimalisasi fungsi ruangruang badan air, seperti sungai, waduk, embung dan bentuk ruang air yang lain maka peran RTB di wilayah perkotaan dalam upaya mitigasi bencana dapat di maksimalkan. Perencanaan RTB ini tidak hanya bertujuan untuk mengoptimalkan fungsi badan air saja, namun juga sebagai upaya untuk melestarikan lingkungan sehingga menunjang bagi perwujudan pembangunan kota yang berkelanjutan (Wessells, 2014). Selain itu keberadaan ruang biru perkotaan dapat digunakan juga sebagai sarana peningkatan kesejahteraan dengan menunjang kesehatan fisik dan psikologis masyarakat melalui kegiatan relaksasi, rekreasi, dan berinteraksi sosial bagi masyarakat, serta memunculkan adanya ekosistem baru di lingkungan perkotaan (Pearson et al., 2017).

\section{Rencana Tata Ruang Wilayah (RTRW) Kota Semarang}

Upaya pengurangan dampak banjir di Kota Semarang secara signifikan dilakukan dengan merencanakan ruang-ruang biru di Kota Semarang yang dituangkan dalam perencanaan tata ruang dan penggunaan lahan. Perencanaan tata ruang dan penggunaan lahan adalah jawaban untuk masalah koordinasi atau integrasi dimensi spasial sectoral kebijakan melalui strategi berbasis teritorial (Cullingworth \& Nadin, 2006). Perencanaan tata ruang dan penggunaan lahan Kota Semarang yang termuat dalam Peraturan Daerah Kota Semarang Nomor 14 Tahun 2011 tentang Rencana Tata Ruang Wilayah Kota Semarang Tahun 2011-2031 (Perda Nomor 14/2011) merupakan pedoman penataan ruang yang digunakan sebagai dasar dalam pemanfaatan ruang wilayah Kota Semarang.

Rencana penataan ruang untuk mengurangi dampak banjir dengan merencanakan RTB perkotaan di Perda Nomor 14/2011 melalui kebijakan dan strategi pengembangan 
struktur ruang, yaitu berupa strategi peningkatan kualitas dan jangkauan pelayanan sistem prasarana sarana umum melalui pengembangan prasarana sumber daya air. Dari point tersebut kemudian dijabarkan dalam beberapa hal yaitu:

1. Pengembangan sistem prasarana air baku dan irigasi, meliputi:

a. Rencana penanganan terhadap daerah aliran sungai (DAS) berupa peningkatan kualitas daerah aliran sungai pada Wilayah Sungai Jratunseluna meliputi:

- DAS Lintas Kabupaten/Kota terdiri dari: DAS Banjir Kanal Barat, DAS Banjir Kanal Timur, DAS Babon

- DAS Dalam Kota terdiri dari: DAS Mangkang Kulon, DAS Mangkang, DAS Mangkang Wetan, DAS Beringin, DAS Randugarut DAS Boom Karanganyar, DAS Tapak, DAS Tugurejo, DAS Jumbleng, DAS Silandak/ Tambakharjo, DAS Siangker, DAS Tawang/ Karangayu, DAS Semarang/ Asin, DAS Baru, DAS Tenggang, DAS Sringin.

b. Rencana penanganan terhadap daerah irigasi (D.I) berupa perlindungan jaringan irigasi meliputi:

- D.I Lintas Kabupaten/Kota, meliputi: D.I Penggaron, D.I Sidopangus, D.I Dolok

- D.I Dalam Kota meliputi 76 DI

c. Rencana pengembangan waduk dan embung meliputi:

- Rencana pengembangan waduk terdapat pada sub sistem drainase Sungai Banjir Kanal Barat terdiri dari:

- Waduk Jatibarang dengan luas \pm 127 Ha berada di Kelurahan Kedungpane Kecamatan Mijen, Kelurahan Kandri dan Jatirejo Kecamatan Gunungpati;

- Waduk Kripik dengan luas \pm 230 Ha berada di Kelurahan Sadeng, Kelurahan Sukorejo, Kelurahan Sekaran, Kelurahan Kalisegoro dan Kelurahan Pongangan Kecamatan Gunungpati;

- Waduk Mundingan dengan luas $\pm 203 \mathrm{Ha}$ berada di Kelurahan Jatibarang, Kelurahan Purwosari dan Kelurahan Mijen Kecamatan Mijen dan Kelurahan Cepoko Kecamatan Gunungpati; dan

- Waduk Garang dengan luas \pm 64 Ha berada di Kelurahan Pakintelan Kecamatan Gunungpati dan Kelurahan Pudakpayung Kecamatan Banyumanik.

- Rencana pengembangan embung pada sub sistem drinase sungai meliputi:

- Rencana embung pada sub sistem drainase Sungai Mangkang meliputi : Embung Wonosari di Kelurahan Wonosari, Embung Tambakaji di Kelurahan Tambakaji, Embung Bringin di Kelurahan Bringin dan Kelurahan Gondoriyo, Embung Kedungpane di Kelurahan Kedungpane dan Embung Wates di Kelurahan Wates;

- Rencana embung pada sub sistem drainase Sungai Plumbon meliputi Embung Ngadirgo di Kelurahan Ngadirgo;

- Rencana embung pada sub sistem drainase Sungai Silandak meliputi Embung Purwoyoso di Kelurahan Purwoyoso dan Embung Bambankerep di Kelurahan Bambankerep;

- Rencana embung pada sub sistem drainase Sungai Madukoro meliputi Embung Madukoro di Kelurahan Tawangmas;

- Rencana embung pada sub sistem drainase Sungai Semarang Indah meliputi Embung Semarang Indah di Kelurahan Krobokan;

- Rencana embung pada sub sistem drainase Sungai Banjir Kanal Timur meliputi Embung Sambiroto I di Kelurahan Sambiroto, Embung Sambiroto II di Kelurahan Sambiroto, Embung Jangli di Kelurahan Jangli dan Embung Mangunharjo di Kelurahan Mangunharjo; dan

- Rencana embung pada Sub Sistem Drainase Sungai Babon meliputi Embung Bulusan di Kelurahan Bulusan, Embung Undip di Kelurahan Tembalang, Embung Gedawang di Kelurahan Gedawang dan Embung Rowosari di Kelurahan Rowosari. 
2. Pengendalian rob dan banjir, meliputi:

a. Pengembangan kolam tampung air di Kecamatan Semarang Utara;

b. Pengembangan tanggul pantai di Kecamatan Tugu, Kecamatan Semarang Barat, Kecamatan Semarang Utara dan Kecamatan Genuk;

c. Normalisasi aliran sungai di seluruh wilayah Kota Semarang;

d. Peningkatan kualitas jaringan drainase di seluruh wilayah Kota Semarang salah satu upayanya melalui pengerukan saluran drainase sampai muara sungai.

Disamping melalui pengembangan prasarana sumber daya air, upaya pengendalian banjir dalam RTRW tertuang pada Pasal 9, ayat 3 huruf e mengenai rencana pengembangan infrastruktur perkotaan yang kemudian dijelaskan lebih lanjut pada Pasal 37 huruf d yaitu rencana sistem drainase. Dari point tersebut kemudian dijabarkan lebih lanjut pada Pasal 45 yang menjelaskan mengenai rencana sistem prasarana drainase di Kota Semarang, meliputi:

1. Sistem drainase Mangkang

Sistem drainase ini memiliki luas daerah aliran sungai \pm 9.272 Ha yang meliputi:

a. Sub Sistem Sungai Mangkang dengan luas \pm 4.372 Ha terdiri dari Sungai Mangkang Kulon, Mangkang Wetan dan Plumbon; dan

b. Sub Sistem Sungai Bringin dengan luas \pm 4.900 Ha terdiri dari Sungai Bringin, Sungai Randugarut, Sungai Karanganyar dan Sungai Tapak.

2. Sistem drainase Semarang Barat

Sistem drainase ini memiliki luas daerah aliran sungai \pm 3.104 Ha yang meliputi:

a. Sub Sistem Sungai Tugurejo dengan luas $\pm 733 \mathrm{Ha}$ meliputi Sungai Jumbleng, Sungai Buntu, Sungai Tambak Harjo dan Sungai Tugurejo;

b. Sub Sistem Sungai Silandak dengan luas $\pm 926 \mathrm{Ha}$;

c. Sub Sistem Sungai Siangker dengan luas \pm 1.022 Ha meliputi saluran Madukoro, Sungai Tawang, Sungai Karangayu, Sungai Ronggolawe dan Sungai Siangker; dan

d. Sub Sistem Bandar Udara Ahmad Yani dengan luas \pm 424 Ha adalah Saluran Lingkar Selatan Barat yang meliputi Sungai Selinga, Sungai Simangu, Sungai Tawang dan Sungai Banteng yang merupakan kawasan drainase semi tertutup.

3. Sistem Drainase Semarang Tengah

Sistem drainase ini memiliki luas daerah aliran sungai \pm 22.307 Ha yang meliputi:

a. Sub Sistem Sungai Banjir Kanal Barat dengan luas \pm 2.005 Ha meliputi Sungai Kripik, Sungai Kreo dan Sungai Garang terletak di Kota Semarang dan Kabupaten Semarang;

b. Sub Sistem Sungai Bulu dengan luas \pm 94 Ha meliputi Saluran J1. Hasanudin, Saluran J1. Brotojoyo, Saluran Panggung Kidul dan Saluran Bulu Lor;

c. Sub Sistem Sungai Semarang dengan luas $\pm 1.352 \mathrm{Ha}$;

d. Sub Sistem Sungai Simpang Lima dengan luas $\pm 340 \mathrm{Ha}$;

e. Sub Sistem Sungai Banger dengan luas $\pm 524 \mathrm{Ha}$.

f. Sub Sistem Sungai Bandarharjo dengan luas $\pm 302 \mathrm{Ha}$;

g. Sub Sistem Sungai Asin dengan luas $\pm 282 \mathrm{Ha}$; dan

h. Sub Sistem Sungai Baru dengan luas $\pm 186 \mathrm{Ha}$.

4. Sistem Drainase Semarang Timur

Sistem drainase ini memiliki luas daerah aliran sungai \pm 31.043 Ha yang meliputi:

a. Sub Sistem Banjir Kanal Timur dengan luas \pm 3.705 Ha meliputi Sungai Candi, Sungai Bajak, Sungai Kedungmundu dan Saluran Bulu Lor;

b. Sub Sistem Sungai Tenggang dengan luas $\pm 1.138 \mathrm{Ha}$;

c. Sub Sistem Sungai Sringin dengan luas $\pm 1.527 \mathrm{Ha}$;

d. Sub Sistem Sungai Babon dengan luas \pm 12.715 Ha meliputi Sungai Gede, Sungai Meteseh, Sungai Jetak dan Sungai Sedoro; dan

e. Sub Sistem Sungai Pedurungan dengan luas $\pm 1.077 \mathrm{Ha}$.

Berikut ini merupakan rencana pengendalian banjir melalui sebaran RTB yang terdapat di Kota Semarang berdasarkan RTRW tahun 2011-2031. Adapun yang termasuk 
dalam RTB ini adalah aliran sungai sebagai drainase alami, embung dan badan air, serta sabuk saluran yang melintasi Kota Semarang.

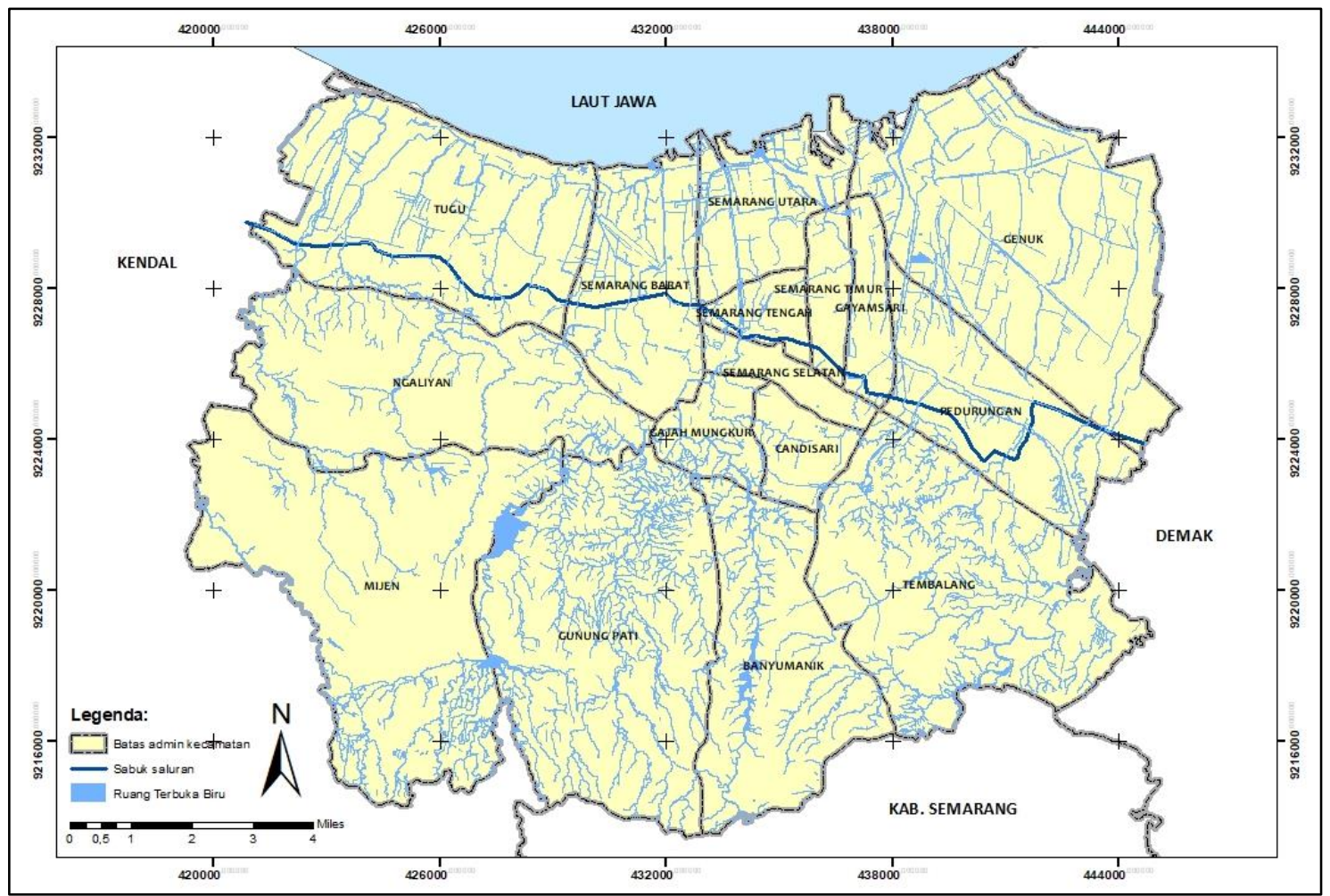

Sumber: RTRW Kota Semarang Tahun 2011 - 2031

\section{Gambar 2. Sebaran Ruang Terbuka Biru Kota Semarang}

\section{Integrasi RTB di RTRW Kota Semarang}

RTRW Kota berdasarkan Peraturan Menteri Agraria dan Tata Ruang/Kepala Badan Pertanahan Nasional Republik Indonesia Nomor 1 Tahun 2018 tentang Pedoman Penyusunan Rencana Tata Ruang Wilayah Provinsi, Kabupaten dan Kota memuat tujuan, kebijakan, dan strategi penataan ruang; rencana struktur ruang; rencana pola ruang; penetapan kawasan strategis kota; arahan pemanfaatan ruang; dan ketentuan pengendalian pemanfaatan ruang di wilayah kota. Guna memperjelas peran rencana tata ruang sebagai salah satu dokumen mitigasi bencana melalui optimalisasi fungsi RTB, maka integrasi RTB pada muatan RTRW Kota Semarang dapat dilakukan pada:

1. Tujuan, Kebijakan dan Strategi Penataan Ruang

Integrasi rencana penataan ruang dalam mitigasi bencana banjir dimulai dari tujuan, kebijakan dan strategi penataan ruang yang merupakan terjemahan dari visi dan misi pengembangan wilayah provinsi, kabupaten atau kota yang dapat dicapai dalam jangka waktu 20 (dua puluh) tahun. Untuk itu dalam menyusun tujuan, kebijakan dan strategi penataan ruang melibatkan banyak komponen kebijakan dan peraturan perundangan. Dalam ilmu perubahan-tanah, perencanaan tata ruang sering diklasifikasikan sebagai politik driver (Lambin \& Geist, 2006). Sedangkan dalam ilmu politik, perencanaan dianggap sebagai kebijakan publik (Paul Sabatier \& Jenkins-Smith, 1999).

Tujuan Penataan Ruang Wilayah Kota, yang dirumuskan dengan Kriteria (Permen No 1/2018): 
a. Mendukung tujuan penataan ruang yang tercantum pada RTR di atasnya (RTRW nasional dan rencana rincinya, serta RTRW provinsi dan rencana rincinya) melalui keterpaduan antar sektor, wilayah, dan Masyarakat;

b. Mewujudkan aspek keruangan yang harmonis dengan Rencana Pembangunan Jangka Panjang Daerah (RPJPD) kota;

c. Mengakomodasi fungsi dan peran kota yang telah ditetapkan dalam RTRW nasional, serta RTRW provinsi;

d. Memperhatikan isu strategis, potensi unggulan dan karakteristik wilayah kota;

e. Jelas, spesifik,terukur dan dapat dicapai dalam jangka waktu perencanaan 20 (dua puluh) tahun; dan

f. Tidak bertentangan dengan peraturan perundang-undangan.

Kebijakan Penataan Ruang Wilayah Kota, yang dirumuskan dengan kriteria (Permen No 1/2018):

a. Mampu menjabarkan tujuan penataan ruang wilayah kota;

b. Mampu menjawab isu strategis di wilayah kota;

c. Mempertimbangkan kapasitas sumber daya yang dimiliki; dan

d. Tidak bertentangan dengan peraturan perundang-undangan.

Strategi Penataan Ruang Wilayah Kota, yang dirumuskan dengan kriteria (permen no 1/2018):

a. Menjabarkan kebijakan penataan ruang wilayah kota ke dalam langkah-langkah yang dirinci dengan target pencapaian 5 (lima tahunan);

b. Harus dapat dijabarkan secara spasial dalam rencana struktur ruang dan rencana pola ruang wilayah kota;

c. Berfungsi sebagai arahan bagi penyusunan indikasi program utama dalam RTRW Kota;

d. Berfungsi sebagai dasar penetapan ketentuan pengendalian pemanfaatan ruang wilayah kota;

e. Jelas, realistis, dan dapat diimplementasikan dalam jangka waktu perencanaan; dan

f. Tidak bertentangan dengan peraturan perundang-undangan.

Dari kriteria kriteria tersebut salah satu yang paling pokok adalah memperhatikan isu strategis, potensi unggulan dan karakteristik wilayah kota dan menjawab isu strategis tersebut dengan mempertimbangkan kapasitas sumber daya yang dimiliki.

Salah satu isu strategis Kota Semarang adalah banjir karena okupansi lahan terbangun ke lahan non terbangun yang berfungsi sebagai area resapan. Isu tersebut akan menimbulkan pengaruh pada tujuan, kebijakan dan strategi penataan ruang. Dalam perencanaannya, RTB sangat erat kaitannya dengan konsep pengembangan "blue infrastructure". Konsep ini merupakan konsep pembangunan yang mirip dengan konsep pembangunan peka air ("water sensitive planning and design"), pembangunan dengan sistem drainase yang berkelanjutan, pembangunan dengan dampak rendah ("low impact development") dan "sponge city" (Planning Department, 2016). Atas dasar hal tersebut maka perencanaan RTB sebagai bentuk integrasi tata ruang dengan upaya mitigasi bencana dapat diupayakan mulai dari perumusan tujuan, kebijakan, dan strategi penataan ruang yang merujuk pada salah isu strategis Kota Semarang yang cukup krusial yaitu banjir.

2. Rencana Struktur Ruang;

Berdasarkan Permen No 1/2018, rencana struktur ruang wilayah kota adalah rencana susunan pusat-pusat pelayanan (rencana sistem perkotaan wilayah kota dalam wilayah pelayanannya) dan sistem jaringan prasarana wilayah kota yang dikembangkan untuk melayani kegiatan skala kota dan mengintegrasikan wilayah kota. Sistem pusatpusat pelayanan kegiatan kota tersebut di atas dapat berupa pusat perekonomian, rencana kota baru, simpul ekonomi baru, dan/atau koridor ekonomi baru yang 
dibutuhkan untuk menjaga keseimbangan ruang, keberlanjutan pembangunan, dan ketahanan masyarakat.

Rencana struktur ruang wilayah kota terdiri dari pusat kegiatan di wilayah kota dan sistem jaringan prasarana maka pengaturan tentang RTB dapat diatur dalam sistem jaringan prasarana.

1. RTB masuk dalam sistem jaringan sumber daya air. Dalam hal ini RTB yang diatur adalah berupa jaringan ruang biru (blue space network) melalui perencanaan infrastruktur biru (blue infrastruktur), yaitu meliputi:

a. Sistem jaringan sumber daya air lintas negara, lintas provinsi dan lintas kabupaten/kota yang berada di wilayah kota, dapat meliputi: sumber air; dan/atau prasarana sumber daya air.

b. Sistem jaringan sumber daya air kota, dapat meliputi:

- Sumber air, yang dapat meliputi: air permukaan pada sungai, mata air, danau, embung, waduk, dan sumber air lain yang terdapat pada permukaan tanah di wilayah kota; dan/atau air tanah pada cekungan air tanah (CAT) di wilayah kota; Sumber air dimaksud yang berada di dalam wilayah kota dapat digambarkan dalam peta rencana struktur ruang wilayah kota apabila diperlukan.

- Prasarana sumber daya air, yang dapat meliputi: sistem jaringan irigasi; sistem pengendalian banjir; dan/atau jaringan air baku untuk air bersih.

Melalui perencanaan blue infrastructure ini, mampu membantu untuk mengefektifkan strategi penguatan ketahanan kota guna mewujudkan pembangunan yang berkelanjutan. Perencanaan tersebut berupa pemeliharaan badan air seperti pelestarian sungai serta pembangunan embung dan waduk, dan mengupayakan sistem drainase yang baik. Jika para perencana kota bisa mewujudkan RTB di daerah perbukitan Kota Semarang maka limpasan air hujan yang harusnya ditampung oleh sungai-sungai di bagian hilir akan semakin berkurang. RTB disini berfungsi sebagai bioretention yaitu penghambat/ mengurangi runoff, meningkatkan supply air, meningkatkan cadangan air tanah, meningkatkan kualitas udara, mengurangai emisi karbon di udara, mengurangi efek urban heat island, meningkatkan kenyamanan tempat tinggal, meningkatkan edukasi publik dan transportasi (Li \& Zhou, 2019).

Tidak menutup kemungkinan RTB ini juga dibuat di bagian hilir sebagai ruang tangkap rob. Konversi lahan dari sawah dan tambak di bagian pesisir Kota Semarang sebenarnya juga menjadi salah satu penyebab semakin luasnya daerah genangan air. Tahun 1980-an, mega proyek industrialisasi yang berada di pesisir Kota Semarang telah mengkonversi areal tambak dan sawah menjadi pabrik. Sawah dan tambak yang secara alamiah bisa menjadi daerah tangkapan air di kala ada luapan air laut saat ini sudah kehilangan fungsi utamanya (Sarifuddin \& Susanti, 2011). Maka dengan pengaturan struktur ruang wilayah kota yang memasukkan RTB dalam rencananya ini diharapkan untuk mampu menciptakan suatu rencana tata ruang yang mendukung upaya mitigasi bencana dengan mempertahankan dan mengupayakan pelestaraian RTB di Kota Semarang ini.

3. Rencana Pola Ruang Wilayah Kota

Merujuk pada Permen No $1 / 2018$, rencana pola ruang wilayah kota adalah rencana distribusi peruntukan ruang wilayah kota yang meliputi peruntukan ruang untuk fungsi lindung dan fungsi budi daya kota. Sedangkan RTB bukan bagian dari fungsi lindung dan fungsi budi daya kota.

4. Penetapan Kawasan Strategis Wilayah Kota

Kawasan strategis kota merupakan bagian wilayah kota yang penataan ruangnya diprioritaskan karena mempunyai pengaruh sangat penting dalam lingkup wilayah kota di bidang ekonomi, sosial budaya, sumber daya alam dan/atau teknologi tinggi, dan/atau lingkungan hidup. Penentuan kawasan strategis kota lebih bersifat indikatif. Menakar dari isu permasalahan banjir yang semakin meningkat di Kota Semarang baik 
secara frekuensi dan luas maka penetapan RTB sebagai blue infrastructure dapat ditetapkan menjadi kawasan strategis wilayah kota dari sudut kepentingan fungsi dan daya dukung lingkungan hidup.

\section{Arahan Pengendalian Pemanfaatan Ruang}

Arahan pemanfaatan ruang wilayah kota adalah arahan pembangunan/pengembangan wilayah untuk mewujudkan struktur ruang dan pola ruang wilayah kota sesuai dengan RTRW Kota. Hal tersebut dilakukan melalui penyusunan dan pelaksanaan program pembangunan/pengembangan beserta pembiayaannya dalam indikasi program utama jangka menengah lima tahunan sampai akhir tahun perencanaan 20 (dua puluh) tahun. Pada perwujudan rencana struktur wilayah kota diantaranya adalah perwujudan sistem jaringan sumber daya air yang merupakan RTB dalam muatan RTRW. Atas dasar hal tersebut maka arahan pengendalian pemanfaatan ruang ini diharapkan mampu untuk menjaga eksistensi RTB sehingga pemenuhan kebutuhan akan ruang terbangun tersebut tidak mempengaruhi dan mendukung fungsi RTB kota yang sudah direncanakan sebelumnya, terutama fungsi mitigasi bencana banjir Kota Semarang.

\section{KESIMPULAN}

Keberadaan ruang terbuka biru (blue space) berpengaruh sangat signifikan pada lingkungan dan ekologis, pemberian nilai estetika kota, dukungan aspek fungsional terhadap ketahanan kota tersebut, dan meningkatkan kualitas hidup masyarakat yang tinggal didalamnya. Bentuk ketahanan kota yang mampu diwujudkan dengan adanya perencanaan terhadap RTB yang baik dapat bermanfaat untuk pengaturan suhu kota, sebagai pengaturan aliran air guna pengendalian banjir, meningkatkan kapasitas dan ketahanan lingkungan, serta upaya mitigasi dan adaptasi terhadap perubahan iklim dan bencana lain (Planning Department, 2016). Banyak para ahli berpendapat bahwa blue space merupakan konsep yang menggabungkan antara perencanaan lansekap (landscape planning) dan perencanaan tata air (water planning). Tidak sedikit para ahli yang mengkaitkan blue space planning dengan kesehatan mental penduduk kota melalui penyediaan ruang santai atau ruang rekreasi. Begitupula banyak para tokoh yang mengkaitkan ketersediaan RTB ini dengan biodiversity dan pembuatan ekosistem baru kota. Namun pada tulisan ini mencoba membahas peran RTB untuk ketahanan kota salah satunya sebagai upaya mitigasi bencana banjir di Kota Semarang.

Kota Semarang memiliki bentuk morfologi yang cukup unik, karena kota ini memiliki daerah yang datar dan berada di pesisir dan juga daerah berbukit. Merujuk pada penelitian yang dilakukan oleh Sejati (2018), ada kecenderungan bahwa perkembangan Kota Semarang saat ini menuju ke daerah perbukitan yang berada di bagian selatan dan barat. Jika konversi lahan dari tidak terbangun menjadi daerah terbangun tidak terkontrol maka sangat mungkin limpasan air hujan semakin besar. Infrastruktur yang disiapkan oleh pemerintah kota baru berada di daerah hilir yang akan menampung air limpasan dari daerah perbukitan untuk dialirkan ke laut. Perlu adanya langkah preventif dengan cara menangkap air yang jatuh di daerah perbukitan untuk diserapkan. Semain banyak air perbukitan yang bisa ditangkap dan diresapkan maka beban kerja infrastruktur di bagian hilir akan semakin rendah. Untuk bisa menangkap limpasan air hujan di bagian perbukitan perlu adanya ruang-ruang khusus untuk tangkapan air. Disamping itu RTB juga sangat penting untuk dibuat dibagian hilir mengingat telah banyaknya area tambak dan sawah yang memiliki fungsi alami sebagai tangkapan air alami harus kehilangan fungsinya karena terkonversi oleh mega proyek industrialisasi menjadi pabrik.

Berdasarkan kondisi tersebut maka menjadi suatu hal yang krusial memasukkan rencana RTB pada muatan RTRW Kota Semarang. Hal tersebut dapat dilakukan mulai dari perumusan tujuan, kebijakan, dan strategi penataan ruang hingga arahan pengendalian 
pemanfaatan ruang sehingga upaya integrasi rencana RTB dapat termuat secara menyeluruh dalam komponen RTRW. Dari hasil integrasi ini diharapkan mampu menciptakan suatu rencana tata ruang yang mendukung upaya mitigasi bencana dengan mempertahankan dan mengupayakan pelestaraian RTB di Kota Semarang ini.

\section{UCAPAN TERIMA KASIH}

Penelitian ini didanai oleh Universitas Diponegoro melalui skema penelitian Riset Pengembangan dan Penerapan (RPP) tahun anggaran 2018 dengan research grant no: 47457/UN7.P4.3/PP/2018.

\section{DAFTAR PUSTAKA}

CCROM. (2010). Vulnerability and Adaptation Assessment to Climate Change in Semarang City. Semarang. Retrieved from https://www.acccrn.net/resources/vulnerability-and-adaptation-assessment-climate-changesemarang-city

Cullingworth, B., \& Nadin. (2006). Town and Country Planning in the UK. 14th Edition. London: Routledge.

Departemen Pekerjaan Umum. Pedoman Penyediaan Dan Pemanfaatan Ruang Terbuka Non Hijau (RTNH) Di Wilayah Kota/Kawasan Perkotaan, Pub. L. No. 12/PRT/M/2009 (2009).

Haeffner, M., Jackson-smith, D., Buchert, M., \& Risley, J. (2017). Accessing blue spaces : Social and geographic factors structuring familiarity with, use of , and appreciation of urban waterways. Landscape and Urban Planning, 167(December 2016), 136-146. https://doi.org/10.1016/j.landurbplan.2017.06.008

Handayani, W., \& Rudiarto, I. (2014). Dynamics of Urban Growth in Semarang Metropolitan - Central Java: An Examination Based on Built-Up Area and Population Change. Journal of Geography and Geology, 6(4), 80-87. https://doi.org/10.5539/jgg.v6n4p80

Ka, F., Chan, S., Gri, J. A., Higgitt, D., Xu, S., Zhu, F., ... Thorne, C. R. (2018). "Sponge City ” in China A breakthrough of planning and fl ood risk management in the urban context. Land Use Policy, 76(May 2017), 772-778. https://doi.org/10.1016/j.landusepol.2018.03.005

Katarína Čákyová, * Z. V. (2018). Impact of blue space in architecture and possibilities of using. In MATEC Web of Conferences 174. https://doi.org/https://doi.org/10.1051/matecconf/201817401037

Lambin, E. F., \& Geist, H. J. (2006). Land-Use and Land-Cover Change Local Processes and Global Impacts. London: Springer.

Li, X., \& Zhou, W. (2019). Optimizing urban greenspace spatial pattern to mitigate urban heat island effects : Extending understanding from local to the city scale. Urban Forestry \& Urban Greening, 41(April), 255-263. https://doi.org/10.1016/j.ufug.2019.04.008

Paul Sabatier, \& Jenkins-Smith, H. (1999). Theories of the Policy Process, 2nd Edition. Westview Press.

Pearson, A. L., Bottomley, R., Chambers, T., Thornton, L., Stanley, J., Smith, M., ... Signal, L. (2017). Measuring Blue Space Visibility and 'Blue Recreation' in the Everyday Lives of Children in a Capital City. International Journal of Environmental Research and Public Health, 14(563). https://doi.org/10.3390/ijerph14060563

Planning Department. (2016). Green and Blue Space Conceptual Framework, (October).

R.R.J.C. Jayakody, D. Amarathunga, \& R. H. (2018). NoIntegration of disaster management strategies with planning and designing public open spaces. In Procedia Engineering 212 (2018). 7th International Conference on Building Resilience; Using scientific knowledge to inform policy and practice in disaster risk reduction, ICBR2017 (pp. 954-961). Bangkok.

Sariffuddin, Astuti, K. D., Farhaeni, G., \& Wahdah, L. (2017). Vulnerability Assessment: The Role of Coastal Informal Settlement Growth to Social Vulnerability in Genuk Sub-District, Semarang City. IOP Conference Series: Earth and Environmental Science, 55, 012047. https://doi.org/10.1088/1755-1315/55/1/012047

Sarifuddin, S., \& Susanti, R. (2011). Penilaian Kesejahteraan Masyarakat Untuk Mendukung Permukiman Berkelanjutan Di Kelurahan Terboyo Wetan, Semarang. Makara, Sosial Humaniora, 15(1), $29-42$. https://doi.org/10.7454/mssh.v15i1.892

Sejati, A. W., Buchori, I., \& Rudiarto, I. (2018). The Impact of Urbanization to Forest Degradation in Metropolitan Semarang: A Preliminary Study. IOP Conference Series: Earth and Environmental Science, 123(1). https://doi.org/10.1088/1755-1315/123/1/012011 
Sobolewska-mikulska, K., \& Ritzema, H. (2018). Integration of water management and land consolidation in rural areas to adapt to climate change : Experiences from Poland and the Netherlands. Land Use Policy, 77(June 2018), 498-511. https://doi.org/10.1016/j.landusepol.2018.06.005

Soetomo, S. (2009). Urbanisasi dan Morfologi: Proses Perkembangan Peradaban dan Wadah Ruang Fisiknya, Menuju Ruang Hidup yang Manusiawi. Yogyakarta: Graha Ilmu.

Tingsanchali, T. (2012). Urban flood disaster management. Procedia Engineering, 32, $25-37$. https://doi.org/10.1016/j.proeng.2012.01.1233

Wessells, A. (2014). Urban Blue Space and "The Project of the Century": Doing Justice on the Seattle Waterfront and for Local Residents. Buildings, 4(4), 764-784. https://doi.org/10.3390/buildings4040764 